\title{
DYNAMICS OF DA'WAH COMMUNICATION IN THE MINORITY OF TORAJA MUSLIM
}

\author{
Qaharuddin Tahir, Sattu Alang, Nurhidayat \\ Muhammad Said, Abd. Halik \\ UIN Alauddin Makassar \\ Jl. Pattiro No. 233 Borongloe, Kabupaten Gowa Sulawesi \\ Selatan 92171 \\ Email: tosang@hotmail.com; nurhidayat.said@uin- \\ alauddin.ac.id; abdul.holik@uin-alauddin.ac.id
}

\begin{abstract}
This study discusses the dynamics of da'wah communication that occurs in the Muslim minority area of Tana Toraja. The main problem discussed was how the dynamics of da'wah communication in the Muslim minority area of Tana Toraja. This research is a qualitative research, with a phenomenological approach in the context of da'wah and communication. Data collection was carried out by observation, interviews, and literature review. The data analysis technique was carried out, referring to the data analysis principles put forward by Miles and Huberman. It offers an interactive model analysis system, which consists of three components, namely data reduction, data display, and drawing conclusions. The research suggested that the dynamics of da'wah communication in the Muslim minority areas of Toraja experienced five phases with different dynamics, namely the pre-colonial era, the colonial era, the independence era, the New Order era, and the reform era.
\end{abstract}

Keywords: Dynamics, Communication, Da'wah, Muslim Minorities. 


\section{Introduction}

The process of Islamization in South Sulawesi carried out by the Kingdom of Gowa in the 17th century to the surrounding kingdoms had a great influence on the spread of Islam. the only area that has not been affected by Islamization is Tana Toraja.

Tana Toraja's absence from the process of Islamization of the Kingdom of Gowa is since the Tana Toraja region is under the power of the Luwu Kingdom, the close relationship between the Kingdom of Gowa and Luwu, has been well established through the marriage relationship between the King of Luwu, Datu Patiarase and a daughter from the kingdom of Gowa named Karaeng Riballabugisi in the 17 th century. ${ }^{1}$ Islamization in Tana Toraja was more influenced by the Luwu Kingdom, through trade and marriage relations, the Sidenreng Kingdom through trade relations, and the Tallu Batu Papan Kingdom in the Enrekang area through trade and kinship relations.

Da'wah activities were initially pioneered by outside traders who were Muslim, some of these traders lived and married residents, through their marriages with residents, then some local people embraced Islam. After the Torajan aristocrats began to embrace Islam, Islam began to be widely recognized in society. The development of further dakwah was spearheaded by Muhammadiyah as the first Islamic mass organization to be present in Tana Toraja in 1936, following

\footnotetext{
${ }^{1}$ Sanusi Dg. Mattata, Luwu Dalam Revolusi (Makassar: Bhakti Baru, 1962). p. 73
} 
the presence of the Indonesian Sarekat Islam Party in 1945, then the Office of the Ministry of Religion of Tana Toraja Regency in 1950, Nahdatul Ulama 1960, Wahdah Islamiyah Ormas were the most recent, namely the Year 2008.

\section{Theoretical Study}

The social theory that can be used as a reference in this research, among others, is the theory of symbolic interaction, this theory will help researchers in parsing the problems to be studied in this study. Symbolic interactionism is very closely related to the issue of da'wah communication.

Three critical concepts are needed in compiling a discussion on symbolic interaction theory, namely the human mind (mind), social interaction (self with others) which is used to interpret and mediate the society in which we live. ${ }^{2}$

Symbolic interactionism teaches that humans interact with each other all the time, they share meanings for certain terms and actions and understand events in certain ways too. Society itself emerges from conversations related to individuals. ${ }^{3}$ With the interaction between fellow individuals, it will give rise to similarities in attitude towards a problem.

Thought, according to symbolic interactionism, actually relates to every other aspect including socialization,

${ }^{2}$ Elvinaro Ardiyanto and Bambang Qamaruzzaman, Filsafat Ilmu Komunikasi, Cetakan V. (Bandung: simbiosa Rekatama Media, 2016). p. 135-136.

${ }^{3}$ Stephen W. Litltejohn and Karen A. Foss. Teori Komunikasi, Jakarta: Salemba Humanika, 2009 p. 121 
meaning, symbols, self, interaction, and also society. ${ }^{4}$ Da'wah communication has an important role in changing the perceptions of people who have mistakenly understood the teachings of Islam, and rectifying wrong perceptions, which have been believed by a person so far, but that belief deviates from the Shari'a taught by Islam. In socialization, there are three objects, namely physical objects, social objects, and abstract objects. Each of these objects has a different definition of the object. Each individual will differ in their interpretation of the same object. As Herbert Blumer puts it: "The nature of an object ... consists in the meaning the person imparts its object "(1969b: 11). Each object will be perceived differently by individuals, depending on the depth of understanding they have about the object.

\section{Research Methodology}

The approach used in this research is a qualitative approach based on phenomenological and humanistic philosophies. In the context of communication and dakwah, as well as in the broader context of social sciences and behavioral science, qualitative research methods are sometimes understood to be the opposite of or at least significantly different from quantitative research methods. , the differences that exist include several things, such as goals. ${ }^{5}$

${ }^{4}$ George Ritzer, Teori Sosiologi Modern, p. 274

${ }^{5}$ Pawito, Penelitian Komunikasi Kualitatif, (Yogyakarta: LKIS, 2008), p. 36 
Qualitative research aims to explain a phenomenon in-depth, based on field data.

Theories in the phenomenological tradition assume that people actively interpret their experiences and try to understand the world with their personal experiences. ${ }^{6}$ Phenomenologists emphasize the real experience of a researcher, therefore real experience in the field becomes the main data of reality.

Qualitative research methods are often called naturalistic research methods because the research is carried out in natural conditions (natural setting); it is also called the ethnographic method because initially this method was more widely used for research in the field of cultural anthropology; referred to as a qualitative method because the data collection and analysis is more of a qualitative nature. ${ }^{7}$ Recently, qualitative research has been carried out in various fields of science, especially social sciences.

In this research, the key informants consisted of Islamic religious figures and proselytizing practitioners both personally and from government agencies or Islamic mass organizations who became actors in preaching to the Muslim community in Tana Toraja Regency.

Data collection was carried out in two stages, the first was observation (observation) of the da'wah communication

${ }^{6}$ Stephen W. Litllejohn and Karen A. Fos, Teori Komunikasi "Theories Oh Human Communication", (Jakarta: Salemba Humanika, 2009). p. 57

${ }^{7}$ Sugiyono, Metode Penelitian Kombinasi: Mixed Methods, (Bandung: Alfabeta, 2013), p. 13 
activities. Furthermore, interviews will be held with selected informants. Other data will be obtained from other sources of information related to the research theme through books, magazines, newspapers, online sites, and other sources that support the research.

In-depth interviews as a collaboration between researchers and participants, where what the participants want to discuss is as important as what the interviewer wants to discuss. ${ }^{8}$ It takes the ability to approach the source so that there is psychological closeness, then the interview can run well and obtain the desired data.

Social science research instruments are generally in the form of questionnaires and interview guides. All types of research instruments contain a series of questions about a matter or problem that is the main theme of the research.?

According to Miles and Huberman, qualitative data analysis is reducing data, presenting data, and drawing conclusions. They interpret data reduction as the activity of selecting important and unimportant data from the data that has been collected. They interpreted their data presentation as the structured presentation of information. In conclusion,

${ }^{8}$ Richard West and Lynn H. Turner, Pengantar Teori Komunikasi Analisis dan Aplikasi, (Jakarta: Salembaba Humanika, 2008), p. 83

${ }^{9}$ Bagong Suyanto and Sutinah (editor), Metode Penelitian Sosial: Berbagai Alternatif Pendekatan, (Jakarta: Kencana, 2005). p. 59 
they interpret the data as an interpretation or interpretation of the data that has been presented. ${ }^{10}$

Data analysis using the Miles and Huberman technique is very appropriate to use for field research with data collection methods through interviews and observations because the data obtained is very large so that the steps The right start to do is to reduce the data, so that only the remaining data are related to the research theme, this can make it easier for researchers at the next stage, namely display and concluding. Besides, this analysis technique allows researchers to perform data analysis throughout the data collection process so that the data obtained is correct.

\section{Results and Discussion}

Toraja is the name of the tribe for people who live in the northern part of South Sulawesi. Currently, the Toraja tribe has a population of 462,619 people, who inhabit two districts, namely Tana Toraja Regency, North Toraja Regency. The majority of Torajans embrace Christianity, while some adhere to Islam and the Aluk Todolo sect.

The missionary journey in Tana Toraja experiences various dynamics and involves characters with different roles in each period. To facilitate the discussion, the author divides the dynamics of da'wah based on five periods, including:

${ }^{10}$ Miles and Huberman in Afrizal, Metode Penelitian Kualitatif "Sebuah Uapaya Mendukung Penggunaan Penelitian Kualitatif dalam Berbagai Sisiplin Ilmu" (Depok: Rajawali Press, 2012). p. 174 


\section{The Dynamics of Da'wah in Tana Toraja in the Pre- Colonial Era}

The pre-colonial era began with the presence of the first ruler who controlled Tana Toraja extensively, namely the era of Tomurung Tamboro Langi's rule around the beginning of the XIII century. Tamaboro Langi 'is a pioneer of customary rules known as the sanda saratu' customary rules. ${ }^{11}$ At this time the relationship between Tana Toraja and the outside world or the lowlands was not yet established. Islam has not been recognized by the public.

The contact between Islam and Tana Toraja, when traced from the beginning, it is found evidence of interactions between people who are Muslims from various directions, including people from the Luwu kingdom, from the Kingdom of Gowa, from Sidenreng, of Enrekang especially in trade relations, territorial conquest and marital relations. This relationship continues between one person and another person who has different religious beliefs. The kingdoms of Luwu and Gowa have officially embraced Islam in the XVI century. This is in line with Tangdilintin's study that since the early sixteenth century, many Bugis traders, especially traders from Bugis Bone, Sidenreng, and Luwu came to Tana Toraja. $^{12}$

${ }^{11}$ Tangdilintin, Toraja "Sebuah Penggalian Sejarah dan Budaya,

${ }^{12}$ Tangdilintin, Toraja "Sebuah Penggalian Sejarah dan Budaya, p. 56 
The early history of the entry of Islam is through trade relations, marriage, both the Batualu Sangalla 'version through the Madandan version of Puang Sondong which also goes through marriage. For the Sangalla '/ Batualu version, the Toraja people who first embraced Islam were Puang Sondong, who originally were Aluk Todolo followers. In around 1750, a native Torajan man married a woman of Luwu descent who was Muslim. Because of this marriage, Puang Sondong embraced Islam. As stated by Syamsuddin Faisal that:

In 1750 of the 18th century Puang Sondong converted to Islam by marrying Sabarra'na and Sabanni'na, the grandson of an Opu from Suli, then living in Sondong. ${ }^{13}$

Rangga is a native Tana Toraja woman who also embraced Islam because she married a nobleman of Luwu descent named Opu Daeng Makkalu '. This marriage also became the starting point for the spread of Islam in the Madandan area and its surroundings, this happened around 1876-1880. As stated in the book Toraja Tongkonan and Kerukunan by Nurdin Baturante which states that:

Rangga was the first Torajan to embrace Islam in the Tana Toraja region, which is estimated to be around

${ }^{13}$ Syamsuddin Faisal (65 years), Former Head of KUA Mengkendek District, interview at Mengkendek, Tana Toraja, October 16, 2019 
1876-1880. In his next marriage, this Rangga married Siduppa from Teteaji Sidrap. ${ }^{14}$

Puang Sondong and Rangga, who are known as figures and leaders in their communities, certainly have their charisma and charm, so that there are people who want to follow their religious beliefs. Departing from interfaith marriage, and united in one religious belief, namely Islam, demands the role of Puang Sondong as a husband who must maintain his new religious beliefs. And ensure children and their descendants remain in their Islamic beliefs.

Tana Toraja in the pre-colonial era was still in the territory of the Luwu Kingdom. The relationship between the Tana Toraja aristocrats and the Datu Palace in Luwu is well established. In the late 19th century, relations between Puang of Sa'dan and Balusu were well-established, apart from marital relations, political and cultural relations with Luwu. ${ }^{15}$

In the early period of the arrival of traders from Sidenreng, a figure known to have played a role in inviting his family to live in Makale, namely a trader of Bugis descent, Sidenreng, whose name was Puang Mamullu and Guru Siduppa, from the descendants and relatives of these two people there was mixed marriage with local communities This marriage was converted to Islam.

\footnotetext{
${ }^{14}$ Nurdin Baturante, Toraja Tongkonan dan Kerukunan, p. 181

${ }^{15}$ Terance W. Bigalke, Sejarah Sosial Tana Toraja, p. 43
} 


\section{The Dynamics of Da'wah in Tana Toraja in the Colonial Era (1906-1945)}

The colonial period began when the Dutch first arrived in Tana Toraja, namely from 1906-1941. The Dutch presence in Tana Toraja met with fierce resistance, especially by Pong Tiku and his followers. But this resistance did not last long and was eventually defeated by the Dutch. After the defeat of Pong Tiku, the Dutch confirmed their power in Tana Toraja.

The power of Islam was a force calculated by the Dutch East Indies government, the influence of the Bugis in Tana Toraja was feared as a force that could convert Tana Toraja to Islam, this is as stated by Bigalke, quoting the statement of the Luwu resident Asiten summarizing the government's position in 1913:

The increased security of people and goods since our arrival resulted in more contact - mainly through trade between the inhabitants of the coast and the kafir ethnic groups, brotherhood is being established between the colonized and their former colonizers, Muslims, and infidels, a brotherhood and assimilation which will increase with the economic development of the land and among its inhabitants. There are many things to be happy about about this development and the absence of support for it by the government could be stronger. But there is evil in this brotherhood; firstly, the areas around Rantepao and Makale will embrace Islam younger than before. The Torajans 
who had settled for a while in Palopo were already trying to find work with traders or Europeans who did not eat pork because they felt awkward among the Muslims; in fact, the number circumcised for the same reason is very high.

All of this means, I believe that the time has come to start evangelism, not only in Rantepao and Makale as planned recently but for all pagan lands ... ${ }^{16}$

From the above statement it shows that there were Dutch East Indies colonial concerns about the good relationship between the Toraja people and the Bugis who lived in Tana Toraja, this concern was related to the existence of the Bugis as followers of Islam.

Abdul Gani is an administrator of the Palopo branch of Muhammadiyah with S. Machmud, who comes from Enrekang, then continued his education at the Muhammadiyah School in Palopo, after graduating he became a teacher at the Muhammadiyah Standard school in Masamba. In 1935, he returned to Tana Toraja to develop Muhammadiyah. ${ }^{17}$

Bigalke expressed his opinion about the management of Muhammadiyah Tana Toraja at that time that:

Muhammadiyah is managed functionally to carry out several activities similar to those carried out by GZB

${ }^{16}$ Terance W. Bigalke, Sejarah Sosial Tana Toraja, p. 102

${ }^{17}$ Herman Tahir (51 years), Chairman of Muhammadiyah Makale Branch, Interview, Makale July 10, 2020. 
in Makale-Rantepao. It consisted of an education committee, which until 1939 ran two schools in Rantepao and Makale, a committee responsible for planning and coordinating da'wah activities, and a committee for running the organization's orphanage and medical clinic. Like Mahmud, half a dozen other Muhammadiyah founders in Makale were mostly firstgeneration hybrids who made a living by trading and had high respect for modern education. ${ }^{18}$

The GZB, which was present with the Dutch government, was managed in a modern way and reached out to remote villages. Especially areas that are the basis of Islam, namely in areas bordering Luwu and Enrekang. To hamper the development of Islam as a role model for the people in these areas, the GZB under the Dutch government built schools and sent teachers who also played a role as missionaries in spreading Christian beliefs.

Bigalke describes the development of Islam in Tana Toraja by saying that:

It is not surprising that the first conversions of some groups, as distinguished from the incidental individual, occurred along a cultural boundary with the highland peoples who absorbed the world religion in the nearby lowlands, Islam. On the Palopo side of this border, the pressure was exerted by traveling Islamic religious teachers and converting rulers whose

${ }^{18}$ Terance W. Bigalke, Sejarah Sosial Tana Toraja, p. 164-165 
numbers increased with Dutch entry into the local economy. Improved transport to and from Palopo gave zelfbestuur Luwu more direct access to the upland villages which they delicately tied up through tribute before 1906. One of the most important outcomes was the Islamization of resistance villages into the 20 th century. ${ }^{19}$

The role of Muhammadiyah Groep Makale is not retroactive in developing Muhammadiyah and Islamic preaching. Muhammadiyah also spread the notion of freedom from colonialists. This is why Muhammadiyah was quickly recognized in Tana Toraja and increasingly aroused the people's enthusiasm to fight against the Dutch colonialists. ${ }^{20}$

Seven Muhammadiyah figures who played a role in the construction of mosques and educational facilities in Tana Toraja in the 1930s, among others: Ua 'Ganing as Chairman, Lamadeng as Treasurer, H. Landicing, Paibing, Makkawaru, Muh. Taib and Abd Kadir. In the beginning, he pioneered the construction of Muhammadiyah Junior High School and Muhammadiyah Junior High School on the land donated by H. Landicing. The initial construction of the Makale Grand Mosque was also initiated by the seven figures. ${ }^{21}$

The Muhammadiyah Middle School and PGA Muhammadiyah buildings after they no longer functioned as

\footnotetext{
${ }^{19}$ Terance W. Bigalke, Sejarah Sosial Tana Toraja, p. 180

${ }^{20}$ Herman Tahir (51 years), Chairman of Muhammadiyah Makale Branch, Interview, Makale, July 10, 2020.

${ }^{21}$ Syamsudduha Saleh (65 years), Professor of UIN Alauddin Makassar, grandson of Lamadeng, Interview, Makassar, 18 August 2020.
} 
schools, on this land the Tana Toraja Muhammadiyah Da'wah Center has been built with the main donor HM. Yunus Kadir, former head of PDM Tana Toraja, is widely known for his generosity.

Education was difficult to obtain by the people of Tana Toraja during the colonial period, so the thought of independence was not so strong. This is the basis for Muhammadiyah then to intensify religious and educational development through the activities of recitation-recitation. Even about a year after its establishment, Muhammadiyah was able to establish a madrasa in Rantepao in 1936, and in 1937 it was moved to Makale.

In March 1942, they suddenly disappeared. Between January 11 and March 8, Japanese Eastern Forces swept across all strategic points in the Indonesian archipelago, forcing the Dutch East Indies government to surrender and turning power to Japan. ${ }^{22}$

The educational curriculum from Dutch heritage has also changed after Belandan left Tana Toraja. This is as stated by Herman Tahir that:

During the Japanese colonial period, several curricula made by the Dutch, although not significant, changed. The lesson that most seemed to have changed was in Dutch language lessons which were changed to 
Japanese lessons. Meanwhile, the other lessons did not change significantly. ${ }^{23}$

During the Japanese period, under the Yamamoto administration in Makale-Rantepao, Muhammadiyah was dissolved and its former members established the Small Trade Association (PDK) as a seemingly non-political alternative. The disbandment of Muhammadiyah was officially part of Japan to merge all Islamic organizations into one unified body known as Jamiyah Islamiyah (JI), under the official leadership of Tetsuo Kobayashi, Head of Islamic Affairs in the naval administration. ${ }^{24}$

After the dissolution of the Dutch heritage Zending School, Muhammadiyah schools still had the opportunity for a short time to remain open. This fact is like the opinion that:

The Zending School which was founded by Missionaries supported by the Dutch was closed by the Japanese. Meanwhile, Muhammadiyah Standard schools are still left open. This is a breath of fresh air for Muhammadiyah to aggressively conduct guidance and preach in Tana Toraja. For this reason, the Muhammadiyah leadership in collaboration with the Hizbul Wathan leadership also made the Muhammadiyah school a place of guidance to instill a

${ }^{23}$ Herman Tahir (51 years), Chairman of Muhammadiyah Makale Branch, Interview, Makale, Kab. Tana Toraja, July 10, 2020.

${ }^{24}$ Terance W. Bigalke, Sejarah Sosial Tana Toraja, p. 265 
spirit of nationalism and struggle for Muhammadiyah citizens and students. ${ }^{25}$

The presence of schools as a basis for education and struggle was considered by the Japanese to be a threat to the Japanese existence in Tana Toraja, so the Muhammadiyah schools were eventually closed by the Japanese colonialists. On the consideration of the Muhammadiyah leadership at that time, Guru Machmud, all Muhammadiyah Standard school students, and members of the Pandu Hizbul Wathan (HW) were asked to adjust to the situation and developments that occurred. This was done to organize the movement's strategy so that it was not so visible to Japan. The struggle movement continued to run outside the Japanese colonial control.

Islam began to enter the life of society at large and began to spread to various corners. But the organization of preaching has not been going well, the preaching is still carried out personally, no organization guides the Muslim community.

The perpetrators of da'wah in this period were individuals who had embraced Islam, they mingled in the daily life of society. The delivery of da'wah was still limited to dakwah bil hal, namely da'wah which was shown with good behavior, attitudes and actions so that it could be imitated by people. other.

\footnotetext{
${ }^{25}$ Herman Tahir (51 years), Chairman of Muhammadiyah Makale Branch, Interview, Makale, Kab. Tana Toraja, July 10, 2020.
} 
The challenge of preaching Islam became even more severe after the presence of the Dutch East Indies in Tana Toraja in 1906. The Dutch government fully supported the presence of the Gerefomeerde Zendingsbond (GZB) in 1913, which carried out a Christian mission in Tana Toraja.

GZB stemmed the development of Islam in the border areas of Tana Toraja and areas that were already populated with Muslims such as Enrekang and Luwu, by establishing schools in border areas and sending teachers who taught in the community. The school is open to the public. The GZB movement succeeded in inhibiting the development of Islam.

In 1935, Muhammadiyah began to carry out its da'wah movement in Tana Toraja, the first thing to do was to approach the community and develop an organization to organize dakwah to be more structured and organized. The presence of educational institutions founded by Muhammadiyah makes Muslim communities have other options, apart from attending schools founded by the Christian Zending movement.

Da'wah actors changed with the presence of Muhammadiyah, preaching which was originally carried out by individuals, turned into more collective and organized dakwah through organizations. The da'wah movement began to be carried out collectively by organizing both Muslims who were members of Muhammadiyah and those who had not.

The spirit of fighting for Indonesian independence has spread to all corners of the country, including in Tana 
Toraja. Muhammadiyah together with the community actively fought for the independence of the Republic of Indonesia, through physical resistance, in resistance it carried out, many Muhammadiyah figures and Muhammadiyah youths, who died on the battlefield.

Evidence of Muhammadiyah's involvement in the struggle against the colonialists is the immortalization of the name of Muhammadiyah figures who died in the struggle, becoming the name of the street in Makale City. This is as stated by Sudirman that:

As an appreciation for the services of the Muhammadiyah leaders' struggle against the invaders, the government enshrined the names of these fighters as street names in Makale City, namely Jalan Ikhwan and Jalan Musa. Ihkwan and Musa are the names of two Muhammadiyah youth figures who died in the struggle against the Dutch colonialists. ${ }^{26}$

Da'wah continued to experience dynamics, including that carried out in this period, the dynamics of da'wah both carried out by individuals and those carried out in Islamic organizations such as Muhammadiyah, experienced significant progress.

The success of preaching at that time can be measured by the increase in the number of people who are Muslim, in 1914 around 200 Bugis lived in Rantepao and its

${ }^{26}$ Sudirman (54 years old), Chairman of the Muhammadiyah Tabligh Council PDM Tana Toraja, Interview, Makale, Kab. Tana Toraja July 8, 2020. 
surroundings, in 1930 the total number of Bugis in Makale and Rantepao reached 2100 people. This is as stated by Bigalke who cites Volkstelling 1930, Deel V: 29.93 that:

Of the 3,720 Muslims (1.13\% of the total population) living in Makale-Rantepao in 1930, there were 1,600 ethnic Torajans or $43 \%$, while the rest were Bugis. ${ }^{27}$

This data explains many things including the increase in the number of Bugis ethnic groups living in Tana Toraja from 1914 to 1930, experiencing a significant increase, although according to Bigalke the figures for 1914 are approximate, while the figures in 1930 are the results of the population census.

Another thing that can be read from the data is the comparison between the number of native Toraja Muslims and Bugis Muslim ethnic who live in Makale and Rantepao, namely $43 \%$ and $57 \%$. This shows that the Muslim Torajan population at that time was still dominated by migrants from Bugis who had already settled in Tana Toraja.

The number of Muslim residents stated in the document is only those who live in Makale and Rantepao, while those who live in other areas are not included. In the border areas with Luwu and Enrekang some people embrace Islam.

Most of the Bugis immigrants recorded in the census work as traders, living around the cities of Makale and Rantepao. They played a role in encouraging the development

${ }^{27}$ Terance W. Bigalke, Sejarah Sosial Tana Toraja, p. 161 
of da'wah at that time, in various ways that could attract residents to embrace Islam. The preaching that is being carried out is still da'wah bil hal.

\section{The Dynamics of Da'wah in Tana Toraja during the Era of Independence (1945 - 1965)}

After Indonesia's independence was proclaimed by Soekarno-Hatta on August 17, 1945, various resistance took place throughout Indonesia, not least in Tana Toraja. ${ }^{28}$ Seeing this situation, Muhammadiyah, which long before had built a spirit of struggle, did not remain silent. With various efforts, Muhammadiyah members participated in the struggle to defend the independence that had been proclaimed.

This also happened in Tana Toraja. As an area that was influenced by the Kedatuan Luwu, Tana Toraja was heavily influenced by the struggles that had been waged in Luwu which were mostly driven by Muhammadiyah people. No exception during the revolutionary period defending independence, the role of Muhammadiyah in Tana Toraja was very large.

The Muslim youth leaders from Rantepao who were culturally Torajan and naturally moderate at first felt that they were more closely allied with the Christian youth of Rantepao than with the Muslims in Makale. ${ }^{29}$

${ }^{28}$ Herman Tahir (51 years), Chairman of Muhammadiyah Makale Branch, Interview, Makale, Kab. Tana Toraja, July 10, 2020.

${ }^{29}$ Terance W. Bigalke, Sejarah Sosial Tana Toraja, p. 282 
The difference in views between the Muslim elements of Rantepao and the Muslim elements of Makale is not so sharp, only on how to get the sympathy of the people in carrying out their da'wah, their main goal at that time was to jointly guard and defend the independence of Indonesia which had been proclaimed by Soekarno-Hatta on the 17th. August 1945.

The cultural values of the Makale Islamic community reflect the main influence of the totok Bugis over the peranakan (mestizo) in the city. Perhaps due to the long history of trade between the Bugis settlements in Makale and the lowlands, many Muslims born there married totok men or women from the lowlands, the peranakan elements in Makale followed Bugis culture more strictly than the Bugis-Toraja cultural mix, different from the Muslims in Rantepao. So Muhammadiyah, with its ideals of religious purification, was trapped in Makale while it had difficulty finding a foothold in Rantepao, where Muslims were more able to assimilate. ${ }^{30}$

A few days after the South Sulawesi Kings Conference in Watampone and the South Sulawesi Youth Conference in Sengkang, Datu Luwu, Andi Jemma, made visits to several areas within the Kedatuan Luwu region. This visit was intended to socialize Luwu's stance on independence and also to organize defense cooperation in the border areas. One of the areas visited by Datu Luwu is Tana Toraja. In addition to

${ }^{30}$ Terance W. Bigalke, Sejarah Sosial Tana Toraja, p. 283 
socializing the attitude of Luwu in this area, it is also to overcome the incident of rejecting the Red and White flag.

This tour in Toraja was carried out around 20 October 1945. During this visit, Datu Luwu also brought along a seasoned orator, a very shrewd agitator, and a very experienced propaganda expert, Martin Guli Daeng Mallimpo. Apart from that, the PRI delegates who were assigned to Poso and Kolaka included Andi Moh. Kasim, M. Sanusi Dg. Mattata (Head of Information and Youth Spokesperson for Luwu) and M. Landau. They have not left yet, because the car and motorboat they will be riding in are under repair. ${ }^{31}$

In Toraja, Datu Luwu Andi Jemma held two general meetings which were held in succession, namely the one at the Rantepao market preceded by the raising of the Red and White flag and which was held in a building in Makale attended by 32 District Heads in the Onder Afdeeling area Makale Rantepao and was also attended by community leaders from various groups in Tana Toraja.

At the first general meeting, in front of thousands of Tana Toraja people, Andi Jemma Datu Luwu made a speech expressing Luwu's firm stance in supporting independence. For this reason, Datu invited all District Heads, ParengngeParengnge, Tomakaka-Tomakaka (Village Heads), and thousands of Toraja people to pledge allegiance to the Proclamation of Independence on August 17, 1945. After the

\footnotetext{
${ }^{31}$ Herman Tahir (51 years), Chairman of Muhammadiyah Makale Branch, Interview, Makale, Kab. Tana Toraja, July 10, 2020.
} 
general meeting, a parade was held by young fighters with the people.

Even though at that time the transportation of Luwu - Tana Toraja was still very difficult, the relationship between the two regions was well established, this can be seen in several visits made by Andi Jemma to Tana Toraja to encourage the community to defend independence. ${ }^{32}$

On that occasion, Andi Jemma Datu Luwu inaugurated the Tana Toraja branch of the PRI Luwu branch who at the same time appointed AYK Duma Andi Lolo as the Head of the Tana Toraja Regional Government. Meanwhile, in the second meeting in Makale, M. Sanusi as the Head of Information and Spokesperson for the Youth of Luwu, explained the basics of independence, the goals, and steps that the Luwu youth had taken to face all possibilities. The Government of the Republic of Indonesia also explained the rebuttal of this lying Dutch pamphlet, as well as the attitude and stance of the Luwu Kingdom Government which was announced at Watampone. ${ }^{33}$

Apart from that, the PRI also explained the Indonesian government's rebuttal to the Dutch pamphlets that had been distributed through the air, which meant that the Indonesian people were patiently waiting for the establishment of a legitimate government by the Dutch. Do not forget to also explain the attitude and stance of the Luwu

\footnotetext{
${ }^{32}$ Herman Tahir (51 years), Chairman of Muhammadiyah Makale Branch, Interview, Makale, Kab. Tana Toraja, July 10, 2020.

${ }^{33}$ Sanusi Dg. Mattata, Luwu Dalam Revolusi, p. 237
} 
Kedatuan Government which was announced at Watampone. ${ }^{34}$ One of the missions of the King of Luwu to Tana Toraja was to socialize Luwu's attitude towards the independence of the Republic of Indonesia.

The establishment of the Kedatuan Luwu that was conveyed in the meeting between Andi Djemma Raja Luwu and Andi Mappanjukki Raja Bone, that "the Luwu Kingdom, stands behind the Republic under any circumstances". This statement was conveyed in response to the return of the Netherlands / NICA. ${ }^{35}$

As a result of the propaganda carried out by the Dutch through the flyer, at the meeting, it was seen that many were pessimistic about being able to defend independence, especially if you saw the Dutch weaponry which was much stronger than Indonesia's. Even pro-Dutch people even helped the propaganda by saying that the Netherlands was indeed a smart and smart nation, far smarter than the Indonesian nation. Moreover, they have complete and modern weapons. The soldiers were brave and well trained. Its allies are many and strong, such as America, Britain, and several other powerful countries. The Dutch even defeated the notorious Japan and Germany. So they said, there was no mistaking that the clever Dutch would have come back to power in Indonesia.

${ }^{34}$ Herman Tahir (51 years), Chairman of Muhammadiyah Makale Branch, Interview, Makale, Kab. Tana Toraja, July 10, 2020.

${ }^{35}$ Sanusi Dg. Mattata, Luwu Dalam Revolusi, p. 229 
Answering the audience's doubts about the ability to fight against the Dutch, then M. Sanusi explained that:

In the beginning, we had to give a lot of sacrifices, both energy, property, and soul. But the person who died while defending his rights has "won" because he failed to prove the determination of a holy stand. So a person who does not fall in the struggle, it is not certain that he will achieve true victory, because most likely, after having fought once or twice alongside his son and wife being persecuted by his enemies, and perhaps also persuaded by rank and money, he will run from the struggle and then he dies, then that person cannot be considered victorious, on the contrary, he is a "deviant". So the stance for them, do not be half-assed, but strong and strong. And if we all hold this opinion, it seems that the struggle will not be long, then Belanda will give up, and later you will see. ${ }^{36}$

The most important thing that was expressed in the second meeting was the explanation of the Red and White flag that was rejected by the people because it was considered the flag of Muhammadiyah. This is understandable because Tana Toraja was the basis of sending and mission (Christianity) which was used by the Dutch to provoke the rejection of Indonesian independence.

Sanusi explained that the Red and White flag is not the flag of Muhammadiyah, the Red and White flag is the flag

${ }^{36}$ Sanusi Dg. Mattata, Luwu Dalam Revolusi, p. 237 
of our country. This flag has been used for a long time by several kingdoms in Nusantara, the color is following the nature and character of the Indonesian people who are honest, trustworthy, and courageous. White is the symbol of cleanliness and honesty, and red is the symbol of courage. ${ }^{37}$

During the revolutionary period to defend independence, the role of Muhammadiyah figures in Tana Toraja was very prominent, especially seen in the composition of the PRI Tana Toraja which was inaugurated by Datu Luwu, Andi Jemma during his visit to Tana Toraja. There are many of the administrators coming from Muhammadiyah. The Tana Toraja Youth Leaders at that time were as follows:

During this turbulent period, many Muhammadiyah activists were victims. They were directly involved in fighting to defend Indonesia's independence. The fighters who were shot and their bodies buried in the Rantepao Heroes Cemetery include: Ichwan Rombe, a member of Pandu Hizbul Wathan, shot at Makale Market, Musa, a member of Pandu Hizbul Wathan, shot at Makale Market, Abdul Gani, a member of Pandu Hizbul Wathan, shot at the Market Rantepao and M. Said Marawe, members of Pandu Hizbul Wathan, died because of being mistreated at Makale prison.

The fighters who were exiled to other regions, who came from Muhammadiyah were members of the Pandu Hizbul Wathan, namely: Mallabbang Makkawaru, La Wahe Tarsan Kaluku, and Muhammad Kamase, they were exiled

${ }^{37}$ Sanusi Dg. Mattata, Luwu Dalam Revolusi, p. 238 
from Makale to Makassar then to Layang, Manado, and Gorontalo). ${ }^{38}$

Fighters who received harsh sentences and detained in several prisons, including the Military Detention Center (RTM) included: Balendeng Makkawaru, Pandu Hizbul Wathan members imprisoned in Makale and Layang, Tjora Makkawaru, member of Pandu Hizbul Wathan, imprisoned in Makale and Layang, Timo Makkawaru, Pandu Hizbul Wathan members imprisoned in Makale and Layang, Saila, Pandu Hizbul Wathan members imprisoned in Makale and Layang and Marra, Pandu Hizbul Wathan members imprisoned in Military Detention Centers (RTM).

The fighters detained at the Makale / Masamba prison include: Laha, member of Pandu Hizbul Wathan Masamba, Abu Bakar, member of Pandu Hizbul Wathan Masamba, Puang Rante Allo Makale, Lagha, member of Pandu Hizbul Wathan Makale, Kamaluddin, member of Pandu Hizbul Wathan Makale, Salahuddin, members of Pandu Hizbul Wathan Makale, Sainuddin, members of Pandu Hizbul Wathan Makale, Maru Mangolele Makale and Nur Bitti Makale.

Muhammadiyah as an Islamic organization that has experienced a long journey in the struggle to seize and defend the independence of the Republic of Indonesia is an organization founded by $\mathrm{KH}$ Ahmad Dahlan on the 8th Dzulhijjah 1330 H to coincide with 18 November 1912 AD

\footnotetext{
${ }^{38}$ Herman Tahir (51 years), Chairman of Muhammadiyah Makale Branch, Interview, Makale, Kab. Tana Toraja, July 10, 2020.
} 
in Yogyakarta. ${ }^{39}$ His presence in Tana Toraja contributed greatly to the struggle for and filling independence.

\section{a. The presence of the Makale Rantepao Religious Affairs Office}

After the independence of the Republic of Indonesia on August 17, 1945, the preaching activities in Tana Toraja continued, even more smoothly, government organizations began to be formed from the center to the regions. Including the Indonesian Office of Religious Affairs in 1950, which was formed in Tana Toraja.

Da'wah activities initiated by the Ministry of Religion in the early days were not very active, apart from limited personnel, also because the main purpose of establishing an office was initially to have an orderly administration, especially in matters of marriage.

Da'wah activities are led by the Ministry of Religion of Tana Toraja Regency, the main ones are counseling and formal education. The da'wah activities carried out personally by employees of the Ministry of Religion are carried out outside the official service by joining Islamic organizations and other dakwah institutions.

\section{b. Sarekat Islam in Tana Toraja}

The political role of the Indonesian Sarekat Islam Party (PSII) in Tana Toraja began to appear, marked by its presence in elements of the Indonesian National Committee $(\mathrm{KNI})$, this council was formed like the same councils

\footnotetext{
${ }^{39}$ Muh. Dahlan, Sejarah SosialIslamic Intellectuals, (Makassar: Alauddin University Press, 2014), p. 138
} 
established in Java after September 1945 to help form local governments. revolutionary. ${ }^{40}$

A month after Indonesian independence was recognized, PSII opened a branch in Makale. The arrival of the PSII represented an outreach beyond the province-based loyalties that characterized Bugis-Makassar politics, but Islamic Toraja did not suddenly change their loyalty from the People's Sovereignty Party. ${ }^{41}$

Politically, the Indonesian Sarekat Islam Party (PSII) also played a role in efforts to resolve agrarian conflicts in Tana Toraja in the 1950s, with the involvement of elements of the Indonesian Sarekat Islam Party (PSII) in an organization formed by many influential civil servants, which were named Disputed Land Affairs Committee (PUTS) in 1953.

Later, the Da'wah of the Sarekat Islam in Tana Toraja was developed in Rembon, a location far from downtown Makale. This is as stated by Muhammad Kala'tina that:

After the death of the head of the Tana Toraja Islamic Society, Abu Bakar alias Iyye 'Caddi, I was the leader of the Sarekat Islam and continued his preaching in Rembon. But organizationally the Sarekat Islam is no longer as prominent as it was in its early days. ${ }^{42}$

${ }^{40}$ Terance W. Bigalke, Sejarah SosialTana Toraja, p. 314

${ }^{41}$ Terance W. Bigalke, Sejarah Sosial Tana Toraja, p. 304

${ }^{42}$ Muhammad Kala'tina, Chairperson of the 2019 Tana Toraja Islamic Sarekat, interview in Rembon, Kab. Tana Toraja, October 16, 2020. 
Today, the Da'wah of the Sarekat Islam has begun to fade due to the absence of sustainable regeneration, so that the successors of the Da'wah of the Sarekat Islam are increasingly minimal. People who join the Sarekat Islam forum are decreasing.

\section{c. Darul Islam Movement / Indonesian Islamic Army}

The widespread influence of DI / TII in the Tana Toraja region affects local political life, this is as stated by Bigalke that:

The growth of the Darul Islam movement has serious consequences for the growth of political and religious life in Tana Toraja. The movement did not create a political divide between Christians and Muslims which contributed to the armed fighting in April 1953. Its beginnings were clear even before independence. Nonetheless, the period of Emergency Government had forced Christians and Muslims to cooperate in forming an acceptable government under the Republic of Indonesia which might ultimately reduce the animosity between the two groups. The effect of the Darul Islam is to eradicate whatever potential there may be for political accommodation. ${ }^{43}$

One of the things that attracted some Toraja figures to join DI / TII was the strong PKI influence and their

\footnotetext{
${ }^{43}$ Terance W. Bigalke, Sejarah Sosial Tana Toraja, p. 347
} 
targeting of these figures. This is as stated by Dahlan Bangngapadang that:

The influence of the PKI at that time was widespread in Tana Toraja, the PKI threatened to kill figures who were considered to be opposed to them, the only power respected by the PKI at that time was DI / TII. This is what motivates many Toraja people to choose to become followers of DI / TII guerrilla in the forest. $^{44}$

The sympathy of the people of Tana Toraja for the presence of DI / TII, apart from the fear of the PKI, was also since this movement was considered to carry out Islamic teachings correctly and simply in organizing the corpse.

DI / TII followers were not only among the common people, but also from among the aristocracy. One of the wellknown figures in Tana Toraja as a DI / TII follower is Londong Allo, who is a descendant of Puang Sangalla '.

Qahar Muzakkar as the central figure of DI / TI, on August 7, 1953, in Pasui, Enrekang Regency, proclaimed South Sulawesi and other Eastern Indonesian regions including West Irian as part of the Islamic State of Indonesia based in West Java. ${ }^{45}$ Since then, DI / TII's political direction

${ }^{44}$ Dahlan Bangngapadang (44 years old), Tana Toraja traditional leader, interview, Marinding, July 5, 2020.

${ }^{45}$ Mohammad Natsir Sitonda, Integration of Guerrilla "Darul Islam / Indonesian Islamic Army (DI / TII) into the Unitary State of the Republic of Indonesia (NKRI)", p. 67 
was under the command of Kartosuwiryo in West Java, who wanted to establish the Islamic State of Indonesia (NII).

Military operations succeeded in paralyzing the DI / TII movement, in February 1965 with the killing of Qahar Muzakkar, with the arrest, death, or disappearance of Qahar and his lieutenants since mid-1965, ending the DI / TII rebellion. ${ }^{46}$ Qahar's followers who were scattered in various regions pledged to return to the Unitary State of the Republic of Indonesia.

After the DI / TII guerrilla, there was reconciliation and integration into the Unitary Republic of Indonesia, according to Mohammad Natsir Sitonda, that as a form of guidance to former Some of the DI / TII followers became members of the TNI, another form of guidance was coaching former DI / TII prisoners through the courts. The court process is a forum for guidance because the process of releasing prisoners can be carried out if they have declared a pledge of allegiance to Pancasila and the 45 Constitution. ${ }^{47}$

The presence of DI / TII in Tana Toraja during 19501965 influenced the preaching movement that had been built so far, especially in remote villages located in the area of DI / TII guerrilla operations, there were fear and economic instability, many residents were forced to fleeing outside the village to avoid chaos in their village.

${ }^{46}$ Terance W. Bigalke, Sejarah Sosial Tana Toraja, p. 364.

${ }^{47}$ Mohammad Natsir Sitonda, Integration of Guerrilla "Darul Islam / Indonesian Islamic Army (DI / TII) into the Unitary State of the Republic of Indonesia (NKRI)", p. 128 


\section{d. The presence of Nahdatul Ulama in Tana Toraja}

Nahdatul ulama was present in Tana Toraja after the independence of the Republic of Indonesia, to be precise in the 1960s. His main base in Rantepao, the first layer and chairman of the first Nahdatul Ulama in Tana Toraja is Jamaluddin Nano, Jamaluddin Nano is the son of an Islamic fighter in Tana Toraja named Nano. Initial struggles in dakwah communication were through recitations in mosques and building relationships with the general public. This is in line with what Said Toago said:

Since the past, the recitation has been held every Friday after the implementation of Friday prayers, but some are held on other days, with the motto being stretched at that time is fastabikul khairat or competing in kindness. It was good at that time if the recitation was held by aisiyah mass organization, then the women of Muslimat NU would also participate. ${ }^{48}$ The presence of different members of mass organizations at the recitation program shows that at that time the spirit of togetherness of the Muslims at that time was quite preserved. If there is no togetherness in preaching, it is difficult to reach the goal of preaching.

Nahdatul Ulama and the Muslim community in Rantepao in 1966 played an important role in the construction and laying of the foundation for the construction of an

${ }^{48}$ Said Toago (73 years), Former Head of the Department of Religion of Tana Toraja Regency and Former Head of Nahdatul Ulama Tana Toraja, Interview, Makassar, February 11, 2020. 
Islamic Junior High School then changed to the PGA 4 Years Filial Palopo, then finally changed to Madrasah Tsanawiyah Rantepao, then moved again to Makale until now, and has become a school. the country under the Ministry of Religion.

The Rantepao Islamic community can still take advantage of the legacy Islamic school that was originally pioneered by Nahdatul Ulama. This is as stated by Ahmad Toago that:

The Islamic Education Institute, which houses Kindergarten Schools (TK), Madrasah Ibtidaiyah, (MI), and Madrasah Tsanawiyah (MTS) located in Rantepao was initially initiated by Nahdatul Ulama under the name Al-Ma'arif, until now it is still running and becoming an educational institution for Muslims in general in Rantepao. ${ }^{49}$

Since its inception in Tana Toraja, Nahdatul Ulama has been domiciled in Rantepao and has become the main basis for the development of Islamic da'wah with the Nahdatul Ulama style, which is known to be more accommodating to the culture that develops in society, when compared to Muhammadiyah and Wahdah Islamiyah.

Da'wah communication after the independence of the Republic of Indonesia in 1945-1965 in Tana Toraja, experienced changes along with the presence of other Islamic organizations such as the Indonesian Sarekat Islam Party

${ }^{49}$ Ahmad Toago (70 Years) Chairman of Nahdatul Ulama Tana Toraja, Interview in Tana Toraja, 7 July 2020 
(PSII) which later changed to Sarekat Islam Indonesia, then the presence of Nahdatul Ulama (NU). At the beginning of independence, the political aspirations of the Muslims were represented by the presence of PSII elements in the Preparatory Committee for Indonesian Independence.

After independence, da'wah actors began to vary, from various Islamic organizations, political parties, governments, and individuals. The synergy in preaching continues to occur. So that until the 1960s, at this time the development of da'wah in Tana Toraja experienced significant progress, Muslims got a role in government and the House of Representatives.

Another progress made during this period was the establishment of Islamic Education Institutions from various levels in various locations in Tana Toraja. So that the sons and daughters of the Muslims have no trouble finding educational institutions that will educate them.

\section{The Dynamics of Da'wah in Tana Toraja during the New Order Era (1966-1998)}

The New Order era began when Suharto officially served as President of the Republic of Indonesia in 1966. During the New Order era, the security approach was the government's main concern, including in this case the government-controlled the development of da'wah.

In this era, the dynamics of dakwah communication did not change much when compared to the previous period, the main actors in dakwah in this period came from four 
institutions that had previously struggled with preaching in Tana Toraja, including preachers from Muhammadiyah, Sarekat Islam, and Nahdatul Ulama., which is fully supported by government agencies, namely the Department of Religious Affairs (DINURA) Dati II Tana Toraja, led by Muh. Saing Himo, BA. In the period 1966-1971.

Saing Himo aside from being the Head of the Service is also a Muhammadiyah figure who is active in conducting cadre to remote villages. This is as stated by Syamsudduha that:

During the Saing Himo's leadership in Tana Toraja, Muhammadiyah activities were very lively, Muhammadiyah was active in conducting training and cadres to remote areas such as Buakayu and other areas. ${ }^{50}$

The development of Islam in Tana Toraja at that time experienced significant developments in various fields, youth cadres also went well. Many religious figures came from various institutions and organizations working together to develop da'wah. Islamic religious figures from various circles were involved in the development of da'wah in Tana Toraja.

Among the developments experienced in this period according to Nurdin Baturante, among others:

1) Active Islamic da'wah movements to the villages;

${ }^{50}$ Syamsudduha Saleh (65 years), Professor of UIN Alauddin Makassar, grandson of Lamadeng, Interview, Makassar, August 18, 2020. 
2) Organized office administration up to the District Office of Religious Affairs (KUA);

3) There were potentials for the development of the people at that time, such as:

- The construction of several mosques and prayer rooms in several places such as in Rantepao, Sesean, Rembon, Sangalla 'and several other places besides Makale and Madandan which had been built earlier;

- The construction of schools ranging from Islamic Kindergarten Schools (STKI), fifteen madrasah ibtidaiyah; apart from Makale and Rantepao cities, also in remote villages such as Tabang, Bena ', Bokin, Balalo', Rembon, Salubarani, Uluway, Bolong and Madandan; 4-year Public Religion Teacher Education (PGAN) Rantepao, which has distant class branches in Sangalla ', Rembon, Salubarani and Bena'. All PGAN schools were transformed into Madrasah Tsanawiyah (MTsN).

- The existence of a Social Agency in the form of the Mother and Child Welfare Center (BKIA), which is cared for by Muhammadiyah.

\section{The Dynamics of Da'wah in Tana Toraja in the 1998-Present Reform Era}

There was no significant change in da'wah after the reformation except for changes in the government's treatment of da'wah and preachers. Before the reformation, religious activities, especially Islam, were tightly controlled both in 
terms of da'wah materials, as well as those involved in preaching. In Tana Toraja, post-reformation activities also experienced changes in the approach and freedom of preachers in carrying out the message of da'wah.

The political role of Muslims in Tana Toraja after the Reformation experienced changes. During the New Order era, no Islamic-leaning political party won seats in the Tana Toraja Regency DPRD. The first post-Reform general election was in 1999, the National Mandate Party (PAN) succeeded in passing one cadre to become a member. the legislature. $^{51}$

The district with the largest percentage of Muslims is in Tana Toraja Regency with a percentage of more than 10 percent of the total population in the district. Based on the percentage, the sub-district with the largest percentage of the Muslim population is Rano District with a percentage of $38.04 \%$. Meanwhile, when viewed from the perspective of the largest Muslim population, the sub-district with the largest Muslim population is Makale District, with a Muslim population of 34,272 people or $12.26 \%$ of the total population.

\section{Conclusion}

The dynamics of da'wah communication in the Muslim minority areas of Toraja appear in five phases,

${ }^{51}$ Imran (47 years), Deputy Chairman of the Muhammadiyah Tana Toraja Regional Board, Interview, Karangan, Kab. Tana Toraja, 15 October 2019. 
namely; The pre-colonial era began in the reign of Tamboro Langi, the colonial era (1906-1941), the independence era (1945-1965), the New Order era (1966-1998) and the Reformation Era (1998-present).

\section{REFERENCES}

Afrizal, Metode Penelitian Kualitatif: Sebuah Upaya Mendukung Penggunaan Penelitian Kualitatif dalam Berbagai Disiplin Ilmu, Depok: Rajawalai Press, 2012. Ardiyanto, Elvinaro dan Bambang Qamaruzzaman, Filsafat

Ilmu Komunikasi, Cetakan V; Bandung: Simbiosa Rekatama Media, 2016.

Dahlam Muhammad, Sejarah Sosial Intelektual Islam, Makassar: Alauddin University Press, 2014 Bigalke, W. Terance, Tana Toraja: A Social History of an Indonesian People, Terj. M. Yuanda Zara, Sejarah Sosial Tana Toraja, Yogyakarta: Ombak, 2019.

Litlejohn, Stephen W. dan Karen A. Foss. Teori Komunikasi, Jakarta: Salemba Humanika, 2009.

Mattata, Sanusi Dg, Luwu dalam Revolusi, Cet. II; Makassar: Bhakti Baru, 1962.

Pawito, Penelitian Komunikasi Kualitatif, Yogyakarta: LKIS, 2008.

Ritzer, George. Teori Sosiologi Modern Edisi ke Tujuh; Jakarta: Prenadamedia Group, 2014.

Sitonda Muhammad Natsir, Integrasi Gerilya: Darul Islam/Tentara Islam Indonesia (DI/TII) Ke Negara 
Kesatuan Republik Indonesia, Makassar: Yayasan Pendidikan Muhammad Natsir, 2013

Sugiyono, Metode Penelitian Kombinasi (Mixed Methods), Bandung: Alfabeta, 2013.

Suyanto Bagong dan Sutinah (editor), Metode Penelitian Sosial: Berbagai Alternatif Pendekatan, Jakarta: Kencana, 2005.

Tangdilintin L.T, Toraja: Sebuah Penggalian Sejarah dan Budaya, Makassar: Balai Pelestarian Sejarah dan Nilai Tradisional, 2009.

West, Richard dan Lynn H. Turner, Pengantar Teori Komunikasi; Analisis dan Aplikasi Edisi 3 Buku 2 (Penj. Maria Natalia Damayanti Maer). Jakarta: Salemba Humanika. 2008. 